University of Nebraska - Lincoln

DigitalCommons@University of Nebraska - Lincoln

Faculty Publications - Department of

Philosophy

Philosophy, Department of

$9-1988$

Intellect and Will in Augustine's Confessions

Dan D. Crawford

University of Nebraska - Lincoln, dcrawford1@unl.edu

Follow this and additional works at: https://digitalcommons.unl.edu/philosfacpub

Part of the Philosophy Commons

Crawford, Dan D., "Intellect and Will in Augustine's Confessions" (1988). Faculty Publications - Department of Philosophy. 1.

https://digitalcommons.unl.edu/philosfacpub/1

This Article is brought to you for free and open access by the Philosophy, Department of at DigitalCommons@University of Nebraska - Lincoln. It has been accepted for inclusion in Faculty Publications Department of Philosophy by an authorized administrator of DigitalCommons@University of Nebraska - Lincoln. 


\section{INTELLECT AND WILL IN AUGUSTINE'S GONFESSIONS*}

Augustine tells us in the Confessions that his reading of Cicero's Hortensius at the age of nineteen aroused in him a burning 'passion for the wisdom of eternal truth'. He was inspired 'to love wisdom itself, whatever it might be, and to search for it, pursue it, hold it, and embrace it firmly' ${ }^{1}$ And thus he embarked on his arduous journey to the truth, which was at the same time a conversion to Catholic Christianity, and which culminated twelve years later in his experience in the garden in Milan.

In the first part of this paper I will trace Augustine's search for intellectual knowledge and truth - the pathway from Manicheeism to Catholicism by which he achieves what he takes to be a true conception of God. Consideration will be given to the way in which his intellectual progress affects and is affected by the conative side of his nature - his desires, habits and affections. I will then ask whether the insight into God's nature that Augustine achieves suffices to give him the wisdom that he seeks, and will consider his novel suggestion that it does not. We will see that Augustine attempts to set out additional, non-intellectual criteria for attaining knowledge of God where 'knowledge' has a richer sense that involves 'holding' the truth, and 'embracing it fully'. Augustine's conversion to the truth essentially involves a reorienting of the will, a radical change in attitude and motive.

My second concern is with Augustine's conception of how his own will functions in his conversion. Clearly he thinks of his conversion as a process of change within the whole self, but one that culminates in a final act of will. His highly dramatized and metaphorical description of the struggle that goes on within him leading to his final decision is a repository of insight into human willing. I will attempt to elicit from the text of the Confessions Augustine's conception of the will - whether it functions as liberum arbitrium, capable of choosing between presented alternatives, or simply as the executive organ of reason or desire. Secondly, I will consider the extent to which Augustine views himself as contributing by his own initiative both to the

* I wish to thank John Hare, William King, William Alston, Newton Perrin, Peter Moore, and Ludwig Schlecht, each of whom read or heard earlier drafts of this paper and made significant criticisms.

1 I am relying on the translation of the Confessions by R. S. Pine-Coffin (London: Penguin, I96I), and I will adopt his division of the work into books and chapters. The passage cited is from Book mi, chapter 4 , pp. 58-9. 
overall process of conversion and to the final moment of decision. Consideration of Augustine's participation in the process must take into account his explicit recognition that he is in St Paul's predicament of not being able to do what he wants to do. The relevant questions are: What does Augustine do to bring about his conversion? and Is his final decision something that he accomplishes by his own effort and striving?

I should acknowledge at the outset of this discussion that this study is based almost exclusively on the text of the Confessions. However, as I will indicate, my reading of Augustine on the will and its activity coheres with that other related work on the will, De Libero Arbitrio, written at approximately the same time as the Confessions.

\section{Knowing and Holding God}

In Books III and IV of the Confessions, Augustine confesses some of the intellectual and moral failings that stood as obstacles in the way of his finding the truth. To begin with, he was led astray by the theological errors and misconceptions of the Manichees. Their fundamental mistake was that they viewed God as a quasi-material reality. Under the influence of these 'sensualists', Augustine conceived God as

a great being with dimensions extending everywhere, throughout infinite space, permeating the whole mass of the world and reaching in all directions beyond it without limit, so that the earth and the sky and all creation were full of you and their limits were within you, while you had no limits at all. ${ }^{1}$

Similarly, he was unable to conceive of the human mind 'except as a rarefied body somehow diffused in space'. ${ }^{2}$

For my mind ranged in imagination over shapes and forms such as are familiar to the eye, and I did not realize that the power of thought, by which I formed these images, was itself something quite different from them. ${ }^{3}$

And further, he adhered to the false doctrine that God and man (in his good part) were beings that had a common nature. 'I thought that you... were a bright unbounded body and I a small piece broken from it'.

From his later vantage point of Catholic belief, Augustine sees that although he had always correctly believed that God is, and is omnipresent, he was fundamentally mistaken about what God is, ${ }^{5}$ and the manner in which all things are in him. He comes to see in retrospect that the Manicheean God he embraced was a 'phantom' lacking in reality and substance.

I gulped down this food, because I thought that it was you. I had no relish for it, because the taste it left in my mouth was not the taste of truth - it could not be, for it was not you but an empty sham. ${ }^{6}$

$$
\begin{array}{ll}
1 \text { vII, I, p. I } 34 . & 2 \text { v, IO, p. I05. } \\
3 \text { vII, I, p. I } 34 . & 4 \text { IV, I6, p. } 89 . \\
5 \text { VI, 5, p. II } 7 . & 6 \text { III, 6, p. 6I }
\end{array}
$$


We will see that Augustine does not escape from these false ideas about God and the self until, much later, he encounters the writings of the Platonists, and through them turns inward to discover his own nature and the source of his being.

Augustine was also prevented from finding the truth by his own moral vices, that is, by certain desires and attitudes which in retrospect he came to view as manifestations of a corrupt will. Thus his ambition to be successful in the fields of law and public speaking was motivated by vanity and conceit. And he speaks of a pervasive attitude of pride and self-esteem that surrounded all of his achievements.

The main defect in the will was that he loved material goods and objects of beauty rather than the source and creator of all good and beautiful things. But just as the Manicheean doctrines did not have the 'taste of truth', so these finite goods were not wholly satisfying. Augustine shows how his love for material things always produced in him some measure of pain and suffering. As contingent and impermanent, they could not give lasting happiness. This was brought home to him in a most convincing manner by the deep and prolonged agony he felt at the death of a boyhood companion. Augustine diagnoses his grief as the result of improper willing: ' I had poured out my soul upon him, like water upon sand, loving a man who was mortal as though he were never to die'. ${ }^{1}$

We may note in the explanation Augustine gives of his suffering an important link between his dislocated will and his intellectual errors. The death of his friend had left him in a state of bewilderment and abject misery. He confesses that he should have placed his heavy load of misery upon God, but could not because he did not think of God 'as anything real and substantial'. 'The God I worshipped was my own delusion, and if I tried to find in it a place to rest my burden, there was nothing there to uphold it. It only fell and weighed me down once more... ${ }^{2}$ The point seems to be that Augustine could not hope to turn away from finite objects as long as his idea of God was fundamentally mistaken. His search for happiness and a place to rest his burdens depended in this way upon his having a true understanding of God.

But if right willing is thus dependent on adequate knowledge, there is a dependency in the other direction as well, for Augustine's false idea of God was grounded in his corrupt will. First, it was engendered by pride, for ' what greater pride could there be than to assert, as I did in my strange madness, that by nature I was what you are'?3 ${ }^{3}$ More generally, it was born of his tendency to think and move among material forms and goods. 'My conception of you was quite untrue, a mere falsehood. It was a fiction based on my own wretched state, not the firm foundation of your bliss'. 4 So it seems

$$
\begin{aligned}
& 1 \text { IV, 8, p. } 79 . \\
& 3 \text { Iv, } 15 \text {, p. } 86 . \\
& 2 \text { Iv, } 7 \text {, p. } 78 . \\
& 4 \text { IV, I6, p. } 88 .
\end{aligned}
$$


true also that Augustine's pride and desire for material goods stand in the way of his forming a correct idea of God. His struggle to attain wisdom, then, will be occurring on two fronts at once.

Augustine describes himself as held captive by his sensuous habits and attitudes and powerless to change them, until the very final episode in the garden. Hence in the early stages, he makes no attempt to alter his desires, but rather devotes himself to a critical examination of his beliefs. It turns out that the same philosophical, questioning temper of mind that had caused him to abandon his early Christian persuasion in favour of the more sophisticated Manicheean doctrines, eventually leads him back to those original beliefs. Interestingly, what causes him to doubt the authority of Manes was that his sacred writings contained scientific errors. Augustine relies on the accurate predictions of the astronomers to call into question the physical theories of the Manichees. He finds the theories of the scientists 'more likely to be true'. ${ }^{1}$ Even if these matters concerning 'the sky and the stars and the movements of the sun and the moon' are 'no part of religious doctrine', nevertheless since Manes claimed that his utterances were those of a divine person, the fact that they were shown to be wrong called into question his religious authority. 'But as he knew no science and yet had the effrontery to try to teach it, he could not possibly have had true wisdom'.2

The scientists, for their part, could not be trusted as truth-bearers, for they do not press far enough in their inquiries, just as Augustine had not in his own liberal studies. In their pride, they fail to discern the creator of the stars, and even to 'inquire how they come to possess the intelligence to make these researches'. ${ }^{3}$ Scientific knowledge, if it is pursued as an end in itself, is wrongly pursued. ${ }^{4}$ But even if Augustine does thus condemn the astronomers and place a merely conditional value upon their inquiries, it should be noted that he had enough confidence in them to use their results to refute the Manichees and thus further his own search for truth.

Disillusioned with Manicheeism, Augustine begins to think that there might be wisdom in the teachings of the Academic philosophers who 'asserted that man can know nothing for certain' ${ }^{5}$ He has reached a moment of intellectual crisis in which all of his beliefs seem doubtful and he despairs of ever finding the truth.

Anxiety about what I could believe as certain gnawed at my heart all the more sharply as I grew more and more ashamed that I had been misled and deluded by promises of certainty for so long, and had talked wildly, like an ignorant child, about so many unconfirmed theories as though they were beyond question. ${ }^{6}$

However, Augustine finds good grounds for rejecting scepticism. He observes that we accept many things on authority and without convincing evidence,

$$
\begin{aligned}
& 1 \mathrm{v}, 3, \text { p. } 93 . \\
& { }^{3} \mathrm{v}, 3, \text { p. } 93 . \\
& 5 \mathrm{v}, \text { io, p. Io4. }
\end{aligned}
$$

${ }^{2} \mathrm{v}, 5, \mathrm{pp} .95^{-6 .}$
${ }_{4} \mathrm{v}, 3, \mathrm{p.} 93$.
${ }^{6} \mathrm{vi}, 4, \mathrm{p} . \mathrm{II} 5$. 
and that 'unless we took these things on trust, we should accomplish absolutely nothing in this life'. 1 We may interpret him as saying that the sceptic's demand that knowledge be indubitable is inconsistent with the epistemic standards we employ in our common beliefs and practices. But Augustine then uses this valid point against scepticism to draw the illicit conclusion that Christians who accept the authority of Scripture on insufficient evidence are justified in doing so. 'I ought not to find fault with those who believed your Bible,... [and] ought to pay no attention to people who asked me how I could be sure that the Scriptures were delivered to mankind by the Spirit of the one true God....'2 Is he claiming simply that it would be inconsistent on his part to accuse the Christian of holding an irrational belief in the authority of Scripture as long as he himself holds many beliefs without sufficient evidence?

Fortunately, Augustine goes beyond this rather innocuous point and attempts to give some positive reason for accepting Scripture as authoritative. Since his own rational efforts have not been able to determine the truth, he concludes that men need some other avenue to the knowledge of God. So, plausibly, God has provided such an avenue in Scripture. Since the Bible is accorded a 'conspicuous authority in every land', it is reasonable to think that God has 'intended it to be the means by which we should look for you and believe in you'. 3 This argument from the universality of belief limps. But I think we should view this lame attempt to give a positive ground as ancillary to his main purpose which is to announce that he is now beginning 'to prefer the Catholic teaching', ${ }^{4}$ and that he is prepared to accept Scripture on faith and without proof. And Scripture is also more palatable now that Ambrose has convinced him that many seemingly absurd passages can be interpreted allegorically. But it bears repeating that the main thrust of this section $(\mathrm{VI}, 5)$ is not to offer rational grounds for belief, but to renounce the need for probative grounds.

Augustine now views Scripture as 'the means by which we should look for you and believe in you'. ${ }^{5}$ And this new commitment reflects a change in the will not only because it involves dispositions to act in certain ways, but also because Augustine has had to swallow his pride to some extent even to think of Scripture as a source of truth. We will see that, at a later stage, this acceptance of scripture plays a crucial role as disclosing the 'path' to the knowledge of God - which is to adopt the Christ-like attitudes of humility and charity.

Augustine now reaches a point where he makes a breakthrough in understanding God's nature. He obtains some 'books of the Platonists' and through them is led to an intellectual vision of God and a new appreciation

\footnotetext{
1 VI, 5, p. II 7.

3 vi, 5, p. II 7 .

5 vi., 5, p. I 1 7. John Hare has reminded me that even Satan accepts the authority of Scripture. Thus Augustine's faith in Scripture certainly does not carry him straightaway to the truth.
} 
of God's nature and his own. The Platonists teach him to look within himself and there to draw back from the confusion of images and consider the power of reason itself and the source of its knowledge. 'I entered, and with the eye of my soul, such as it was, I saw the Light that never changes casting its rays over the same eye of my soul, over my mind' ${ }^{1}$ It was this light that illumined the mind 'when it proclaimed for certain that what was immutable was better than that which was not', and by which 'it had come to know the immutable itself'. Thus Augustine realizes that he has always possessed $a$ priori knowledge, and sees the Light that casts its rays over his mind as the ground of that certainty. 'And so, in an instant of awe, my mind attained to the sight of the God who IS'.2

We will not attempt to evaluate this rational evidence for God that incorporates a partial vision of the object. For our purposes, what is important is that Augustine gains from it an insight into the divine nature that at once dispells error and confusion, and turns aside scepticism. He now takes himself to be objectively certain that God is incorporeal, eternal wisdom, being, and the source of all being. And he claims to have gained knowledge of these truths not through the authority of revelation but through the power of reason.

We find in this episode of Augustine's conversion the highest degree of what Peter Brown calls the 'spiritual autonomy' of the Platonist tradition. Brown points out that 'the Platonists had always felt able to offer a vision of God that a man might gain for himself, by himself, through the unaided, rational "ascent" of his mind to the realm of ideas' ${ }^{3}$ And yet in spite of this common ground with the Platonists, we realize that Augustine is not going all the way with them when, in reflecting on his new insight, he states:

When first I knew you, you raised me up so that I could see that there was something to be seen, but also that I was not yet able to see it.... Your light shone upon me in its brilliance, and I thrilled with love and dread alike. I realized that I was far away from you. ${ }^{4}$

Augustine has certain knowledge of God but is still distant from him. 'I had no doubt at all that you were the one to whom I should cling, only I was not yet able to cling to you'. ' 'I was too weak to enjoy you'. ${ }^{6}$ Augustine is aware that his intellectual vision of God has not given him the full knowledge of the truth that he seeks. The Platonists have raised the curtain, enabling him to know and love God, and yet this encounter with God is deficient in a way that Augustine can only describe in terms of various metaphors of

1 viI, iо, p. I46.

2 viI, I7, p. I 5 I.

3 Peter Brown, Augustine of Hippo (Berkeley: University of California Press, I967, I 969), p. I 03.

4 vir, Io, p. 147.

5 vil, I 7, p. I 5 I.

6 vII, 20, p. I 54. 
possession (holding, clinging to), intimate acquaintance (finding one's home, remaining in, enjoying), and even physical intake:

In my weakness I recoiled and fell back into my old ways, carrying with me nothing but the memory of something that I loved and longed for, as though I had sensed the fragrance of the fare but was not yet able to eat it. ${ }^{1}$

Augustine now focuses on what it is that prevents him from knowing God in this intimate and enduring way. The problem lies in the 'old attachments' within the will. He cannot be steadfast in his love for God as long as he continues to submit to his desires for material ends - honour, wealth, and above all, 'woman's love'.

This acknowledgement of his own pride and resistance in refusing to devote himself to the truth gives Augustine the occasion to show just why the Platonist philosophers come up short. Like the scientists, they are puffed up with pride and hold their heads 'high in the clouds of learning'. 'Although they have the knowledge of God, they do not honour him or give thanks to him as God'. 3 Moreover, their pride is manifest in their failure to recognize the causal role of God in their knowledge of him. They do not appreciate the teaching of Paul that 'he who sees ought not to boast as though what he sees, and even the power by which he sees, had not come to him by gift'. ${ }^{4}$ The Platonists' prescription to turn inward has enabled Augustine to locate the truth, but it is by faith in the Catholic teachings that he is shown the path to it, viz. the sorts of attitudes and commitments by which he can lay hold of it, and bring it into his life and activity. ${ }^{5}$ He sees that he must exchange his attitudes of pride and self-esteem for Christian virtues of humility, piety, and charity, ${ }^{6}$ and replace the old attachments with a life of contemplation and chastity. For Augustine, who we must remember is experiencing conversion, the path to the truth finally comes down to the matter of deciding to adopt a life of humble service. ${ }^{\text {? }}$

1 VII, I 7, p. I 52.

3 vir, 9, pp. I $45^{-6}$ (Romans I : 2 I).

2 VII, 9, p. 145 .

5 I have benefited from David Burrell's formulation of this point in 'Augustine: Understanding as a Personal Quest'. He emphasizes that Augustine, at one and the same time, wanted to 'acknowledge his debt to the neo-Platonists and seek to enlarge the pattern for understanding which they offered to him. The inspiration for a new pattern is manifestly Christian - the difference between a disembodied word and a word made flesh is precisely the increment which discipline adds to insight'. Ch. I in Exercises in Religious Understanding (Notre Dame: University of Notre Dame Press, I974), pp. I I-4I, especially pp. 22-5. The passage cited is on p. 24.

6 vil, 20, p. I54. 'For was I not without charity, which builds its edifice on the firm foundation of humility, that is, on Jesus Christ? But how could I expect that the Platonist books would ever teach me charity'?

${ }^{7}$ We may well ask why Augustine thinks it is necessary to adopt these specifically Christian attitudes in order to lay hold of the truth. The answer, I think, has to do with certain specifically Christian theological doctrines that Augustine has accepted. God is viewed as creator - transcendent and majestic; and man, on his side, has separated himself from God by a sinful act. Within this theological framework, attitudes of humility and reverence become appropriate for one who seeks to know God. The Platonists do not see the need to approach God in this way because they have a fundamentally different conception of God and, more importantly, of God's relation to man. 


\section{The Impotent Will}

Now that Augustine has located the problem of knowing-and-holding God within the sphere of the will, he encounters the problem of the will, namely that he cannot will wholeheartedly what he most desires. He is precisely in $\mathrm{St}$ Paul's position of not being able to do what he would do. His problem is that he lacks the strength of will to do what he wants to do and knows to be best. The will is 'weighed down by habit', and therefore 'does not wholly rise to the heights where it is lifted by the truth'. ${ }^{1}$

This limitation upon the will is put, strikingly, in terms of two conflicting 'wills' within him. There is the old will that wills earthly pleasures, and also a 'new will which had come to life in me and made me wish to serve you freely and enjoy you... [but] was not yet strong enough to overcome the old....'2 I take Augustine to be saying that these two wills are two conflicting (sets of) desires within one will or self. He is not saying that he is split into two agents or selves, for that would be to slip back into the Manicheean error. He repeatedly affirms that it is the same self that acts (or attempts to act) from each of these desires. ${ }^{3}$ Thus he regards the self as something distinct from these wills.

Moreover, he conceives the self as an agent in that it seeks to influence this struggle between his desires. 'In this warfare I was on both sides, but I took the part of that which I approved in myself rather than the part of that which I disapproved'. ${ }^{4}$ An important change has occurred in Augustine, for he is now 'on the side of' the new will. Having discovered the path to God, he is beginning to act from a second-order desire that his first-order desire to devote himself to God should be realized. He seeks to strengthen and encourage in himself his desire for a life of service. 'I cudgelled my soul and belaboured it with reasons why it should follow me now that I was trying so hard to follow you' ${ }^{5} \mathrm{He}$ is angry with himself over his own indecisiveness. ${ }^{6}$ And as he nears the moment of conversion, instead of saying 'not yet', as he had in the past, ${ }^{7}$ he attempts to goad himself into acting: 'In my heart I kept saying "Let it be now, let it be now!", and merely by saying this I was on the point of making the resolution'. 8 In this way, Augustine's initiative has shifted to a higher level: he admits that he cannot simply

\footnotetext{
1 VIII, 9, p. I72. ${ }^{2}$ VIII, 5, p. 164.
}

${ }^{3}$ viII, 5, p. I 65 ; vII, 3 , p. I 36 ; and vII, Io, where he states: 'When I was trying to reach a decision about serving the Lord my God, as I had long intended to do, it was I who willed to take this course and again it was I who willed not to take it. It was I and I alone. But I neither willed to do it nor refused to do it with my full will. So I was at odds with myself' (p. I73). Again, the Manichees should 'cease to deny that when a man tries to make a decision, he has one soul which is torn between conflicting wills' (p. I 74).

5 viII, 7 , p. I 70 .

6 'I was frantic, overcome by violent anger with myself for not accepting your will and entering into your convenant', viII, 8 , p. I 7 I.

7 viII, 7, p. 169 .

${ }^{8}$ viII, II, p. I 75 . 
choose to act from one of his (first-order) desires. ${ }^{1}$ He can only influence his decisions indirectly by seeking to promote and strengthen the desire he favours.

But all of these efforts and stratagems together are insufficient to turn the tide. Although the strength of the old attachments is gradually diminishing, ${ }^{2}$ Augustine still cannot free himself from them. He is unable to resist the old habits, themselves backed by his (second-order) desire to hang on to them. 'They plucked at my garment of flesh and whispered, "Are you going to dismiss us? From this moment we shall never be with you again, for ever and ever". '3 Thus his role seems reduced to that of sideline supporter encouraging the underdog in the contest that rages in the will.

Yet even while emphasizing this inability in the will, Augustine tends to attribute his failure to choose God to his own indecisiveness, as if he only needed to make a greater effort, be more resolute, in order to achieve what he truly desires.

And to reach this goal... no more was required than an act of will. But it must be a resolute and whole-hearted act of the will, not some lame wish which I kept turning over and over in my mind.... ${ }^{4}$

But this tendency to view the problem of the will as one of weakness of will is, I believe, inconsistent with the other involuntarist theme in that it implies that he is able to choose God but will not put forth the required effort. Augustine's use of the language of decision at this stage of his conversion is indeed in accord with the way he has described the process up to this point, namely as depending mightily on his will, but this pattern of thought now collides with the realization that he cannot accomplish his goal by his own efforts.

Finally in the garden, the chaste beauty of Continence invites him 'to cross over and to hesitate no more'. 'Why do you try to stand in your own strength and fail? Cast yourself upon God and have no fear'. 5 Augustine sees finally that he cannot achieve his goal by his own striving. He must relinquish all his attempts to bring about the conversion of his will, and submit to God's initiative. And with this final realization, reinforced by reading the exhortation from Paul's epistle, 'the light of confidence flooded into my heart ', ${ }^{6}$ and he is able to will resolutely and wholeheartedly a life of devotion.

1 'My lower instincts, which had taken firm hold of me, were stronger than the higher, which were untried. And the closer I came to the moment which was to mark the great change in me, the more I shrank from it in horror', vill, 11, p. 175 .

${ }^{2}$ See vili, I, p. 158 and i I, p. I 75, where he refers to the 'worn and slender remnant of my chain'. 'These voices, as I heard them, seemed less than half as loud as they had been before' (p. I 76 ).

3 viI, I I, pp. I $75^{-6}$.

4 viI, 8, p. I 7 I ; 'I tried again and came a little nearer to my goal, and then a little nearer still, so that I could almost reach out and grasp it. But I did not reach it. I could not reach out to it or grasp it, because I held back from the step by which I should die to death and become alive to life', viII, I I, p. I 75 .

5 viII, I I, p. I 76 .

6 viII, I 2, p. I 78 . 


\section{The Will as Liberum Arbitrium}

Let us now try to elicit more fully Augustine's conception of the will or acting self, and the role that he assigns to his own initiative and activity in his conversion. In the following discussion, I will make use of two concepts of the will distinguished by Hannah Arendt in her chapter on Augustine in The Life of the Mind: Willing. The first is that of the will as 'a mere auxiliary executive organ for whatever either desire or reason has proposed'. 'The second is the will as liberum arbitrium, 'the freedom of choice between two or more desirable objects or ways of conduct', both of which are 'equally possible and given to us, as it were, in statu nascendi as mere potentialities'.2 The will functions to realize one of these potentials. Our question, then, is how the will is functioning in Augustine's culminating act: does it opt for one of two alternatives? or does it merely execute the command of reason (reason's desire) when that desire finally becomes stronger than its rival?

It is important to remember, at this point, that Augustine does employ the idea of the will as liberum arbitrium in the nearly contemporaneous work, $D e$ Libero Arbitrio, in which he asserts that men have freely chosen to turn away from God and so have brought upon themselves God's just punishment in the form of human corruption and suffering. ${ }^{3}$ This gives us some initial reason for thinking that Augustine's decisive act is the result of his exercising this same power of choice. On the other hand, even if Augustine allows that he has in some sense turned away from God, this is no guarantee that he can by his own power turn back to God. ${ }^{4}$

But what makes the interpretation of the will as liberum arbitrium plausible is the fact that throughout the account of his conversion, as we have seen, Augustine assigns a significant role to his own individual effort and initiative. And indeed, it would be absurd to deny his active participation in the whole process, or to describe his progress in a way that ignored his own contribution to the outcome. The impress of Augustine's initiative is evident first and foremost in his intellectual struggle, as for example in his dialectical debate with the Manichees and the sceptics. But it is manifest also in various

1 Hannah Arendt, The Life of the Mind, Vol. 2: Willing (New York: Harcourt Brace Jovanovich, I978, I $98 \mathrm{I}), \mathrm{F}^{2} \mathrm{I} 4$.

5 Arendt, p. 29.

3 These passages express this point clearly enough: 'We conclude, therefore, that the movement which, for the sake of pleasure, turns the will from the Creator to the creature belongs to the will itself'. 'If the movement by which the will is turned this way and that were not voluntary and within our power, we could not be praised when we turn toward higher things, or blamed when, as if on a pivot, we turned toward lower ones...' On Free Choice of the Will, trans. A. S. Benjamin and L. H. Hackstaff (Indianapolis: Bobbs-Merrill, I 964, I979), Book Three, pp. 87-8.

4 Augustine states in Book Two of De Libero Arbitrio: 'Since a man cannot rise of his own will as he fell by his own will, let us hold with firm faith the right hand of God, Jesus Christ our Lord, which is stretched out to us' (p. 84). But this is consistent with saying that human souls are blameworthy for not doing what they can (see Book Three xx, pp. I3 $\mathrm{I}^{-3}$ ): 'He justly punishes them because they desire to remain in ignorance and difficulty, and because they are unwilling to arrive at truth and peace through zealously seeking and learning, and humbly confessing and praying' (p. I33). These are just the things that Augustine was able to contribute to his own conversion. 
achievements along the way - in his realization that Scripture has authority, in his recognition that he was a slave to the old habits and needed to replace them with the new, in his turning inward to find the Light within, and finally in the various actions taken to foster and nourish the 'great desire' that had come to life in him. Even the command of Continence to cast himself upon God is something to which he gives his acknowledgement and consent.

But at the same time, we cannot ignore the strong element of passivity in Augustine's account. He speaks as if the transformation in his desires is something that happens to him, and that he is not himself controlling. One sees this of course in the stubborn resistance he finds in the will and in his inability to do what he wants to do. Moreover, the impression is given that, at crucial junctures when he has reached an impasse, it is only by the intervention of some external stimulus or agency that progress is made, as for example when Continence appears to him.

This passive dimension of Augustine's experience is of course consistent with the idea that he himself is affecting the process and contributing to the outcome of his struggle in the aforementioned ways. And if it is allowed that Augustine can contribute in these ways, why cannot it be said that it is he who finally makes the difference, that is, tips the scales in favour of the new will? As the old will diminishes in strength, why can we not suppose that at some point it is weakened enough that he can decide against it?

The chief difficulty about saying this is that while it is theoretically possible to view the act in this way - as an achievement of the liberum arbitrium, Augustine himself emphatically denies that it is. He refuses to give himself credit for an act which, he finally sees, is initiated from without. He sees this only at the very last moment with the realization that he should cease, or better, has ceased, his own striving. ${ }^{1}$ Thus he never has the ability, or acquires the ability, to turn toward God. And so, the culminating act is not his, not the result of his willing.

But it would be a mistake to stop here, and to the extent that Augustine himself does, he fails to appreciate the significance of his own narrative. For it must be remembered that his conversion cannot be identified with the culminating decision but is rather a process, a series of acts that began with the questioning of the Manichean doctrines. And as we have just seen, Augustine did exercise his will heavily throughout this process. To the extent that the conversion process, considered as a whole, is a product of his effort and choosing, it is his accomplishment. The will functions merely as an executive organ with respect to the final decision, but since it initiates other deeds and pursuits in the larger process, it is strictly wrong to say or imply, as Augustine himself does, that he does not function as agent in this process.

1 It could, of course, be maintained that Augustine finally becomes free at the moment of his final decision, viz. in the sense that he is now willing and living in accord with his greatest desire. Our concern, however, has been with whether he has any freedom of choice in reaching this final state. 
It might be argued that the conversion is not his act because its final step is not his. But it can equally be said that the conversion is his act because the earlier steps of forming a clear vision of its object, and of the means or path to the object, and thereby making the initial moves in the right direction, were his.

Finally, it cannot be argued, by a kind of backward projection, that all of these earlier acts were also things that he could not do alone, since there is no suggestion that he encountered any insurmountable resistance within the will with respect to any of them, and so was unable to do them. For instance, he challenges Faustus, and works his way toward a refutation of the Manichean doctrines. So even if Augustine does, after the fact, come to believe that God has somehow guided him toward his goal, this does not mean that his own decisions were not efficacious along the way. Clearly he depends on an outside force to bring about a shift in his desires and attitudes so that they conform to his vision of the truth. But I can find no basis in Augustine's text for saying that he is similarly dependent on God with respect to the series of actions by which he achieves that vision and thus brings himself to the moment of making the great decision. In this way, Augustine depicts the divine initiative as presupposing and conditioned by his own.

Before closing this account of Augustine's conversion, we must mention some further confessions he makes about his post-conversion state. After the garden experience, Augustine's conversion is complete in the sense that he now wills resolutely a life of continence and devotion. The new will within him is stronger than the old. But the old will has not been eradicated. He continues to wrestle with the old tendencies, but now, like his friend and fellow convert Alypius, by way of a much more 'delicate conscience'. In Book X (as Peter Brown has emphasized), Augustine describes his ongoing struggle with sensory pleasures and bodily appetites - some of which have taken refuge in his dreams. The problem, as he sees it, is that he either overindulges these desires, or delights in sensory objects for their own sake rather than as manifestations of the source of all being. To the extent that he yields to these temptations, he suffers sorrow and anguish and is thwarted in his desire to know God completely. 'When at last I cling to you with all my being, for me there will be no more sorrow, no more toil. Then at last I shall be alive with true life, for my life will be wholly filled by you ... but my life is not yet filled by you and I am a burden to myself'. ${ }^{1}$

Albright College, Pennsylvania, U.S.A. 